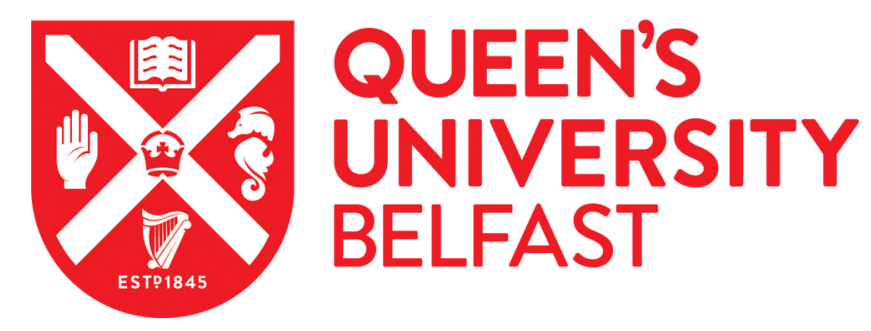

\title{
The Blurred Line Between Theistic Evolution and Intelligent Design
}

Leidenhag, M. (2019). The Blurred Line Between Theistic Evolution and Intelligent Design. Zygon: Journal of Religion and Science. https://doi.org/10.1111/zygo.12556

Published in:

Zygon: Journal of Religion and Science

Document Version:

Peer reviewed version

Queen's University Belfast - Research Portal:

Link to publication record in Queen's University Belfast Research Portal

Publisher rights

Copyright 2019 Wiley. This work is made available online in accordance with the publisher's policies. Please refer to any applicable terms of use of the publisher.

\section{General rights}

Copyright for the publications made accessible via the Queen's University Belfast Research Portal is retained by the author(s) and / or other copyright owners and it is a condition of accessing these publications that users recognise and abide by the legal requirements associated with these rights.

Take down policy

The Research Portal is Queen's institutional repository that provides access to Queen's research output. Every effort has been made to ensure that content in the Research Portal does not infringe any person's rights, or applicable UK laws. If you discover content in the Research Portal that you believe breaches copyright or violates any law, please contact openaccess@qub.ac.uk. 


\section{The Blurred Line between Theistic Evolution and Intelligent Design}

In the apparent culture-wars between science and religion, the relationship between theistic evolution and intelligent design is often framed in terms of a particularly decisive battle: a battle between science and faith, a battle between Church and State, a battle between fundamentalism and liberalism, etc. Theistic evolutionists critique the proponents of intelligent design for undermining the integrity of the natural sciences and misconstruing God's ongoing relationship with nature; and, likewise, those who favor intelligent design critique those who align themselves with theistic evolution for sacrificing faith at the altar of secularism and naturalism. On this battle-framed picture, you choose either theistic evolution (TE) or intelligent design (ID). In this paper I will call into question this often-assumed dichotomy between these two positions in the ongoing dialogue between science and religion, and argue that the line between TE and ID is blurred.

My paper will proceed in the following manner: First, I will introduce some of the central claims of TE and ID. Thereafter, I will scrutinize the claims that some theistic evolutionists make with regard to divine action and God's activity within the natural domain. Notable proponents of TE subscribe to non-interventionist and quasi-_naturalist notions of divine action, suggesting that God only works through natural processes and events. I will refer to this idea as Natural Divine Causation throughout the paper (which I and XXXX also discussed in XXXX). I will argue that it is not only difficult to make conceptual sense of NDC, but that it more problematically introduces significant ambiguities into theistic evolutionism and that it makes God-talk redundant. My advice is for those who subscribe to TE to reject NDC in order to affirm a more robust notion of divine agency. However, as I will go on to explain, if the theistic evolutionists were to give up on NDC, then they would move their position significantly closer to Intelligent Design. 
After having critiqued the philosophical ambiguity of NDC, I discuss several different ways of defending NDC as both a position in the divine action debate and as a way to draw a line between theistic evolution and intelligent design. It will be seen, however, that none of these lines of defense is are successful. Hence, the line between theistic evolution and intelligent design is blurred.

It should be stressed from the start that this is not an argument for intelligent design. Indeed, I find the claims of ID theologically thorny, philosophically dubious, and scientifically problematic. My goal with this article is to shed light on and critique one commonly proposed way of framing the boundary line between intelligent design and theistic evolution. This paper leaves open, then, the possibility that there are other ways of highlighting the difference between TE and ID.

\section{Brief Survey of Intelligent Design and Theistic Evolution}

Others have provided excellent overviews of both theistic evolution and intelligent design and the relationship between them, so I will keep this section fairly short and to the point (see especially Kojonen 2013; 2016). Let us start off with what has become known as Intelligent Design, as this will help us to understand the theistic evolutionist attempt at formulating an account of divine activity consistent with a modest form of naturalism that does not rely on gaps in scientific knowledge.

Historically connected to Young Earth Creationism or Biblical Creationism, the fundamental claim of ID is that "the best explanation for at least some of the appearance of design in nature is that this design is actual" (Menuge 2007, 32). ${ }^{1}$ That is, contrary to the

1 I will not discuss whether ID is a religious hypothesis. In Barbara Forrest's treatment of the intelligent design movement, it is claimed that ID is intrinsically religious, due to the history of this movement and the motivation behind many proponents of intelligent design (see, for example, Forrest 2004). However, I am inclined to agree with those that argue that the thesis of intelligent design is not intrinsically religious, but that it potentially carries religious and metaphysical implications (see Meyer 2009, 441-448). 
Dawkinsian idea that the biological world merely gives the appearance of having been designed (Dawkins 1986), the ID proponent maintains that design is a real feature of reality and that the "observed complexity and information-rich structures found in living systems and other features of life" require an intelligent cause or designer (Meyer 2017, 179). While "hard-core" creationism requires an outright rejection of the Darwinian synthesis (with the exception of small-scale microevolution), intelligent design accepts important parts of modern Darwinism. First, many people in the intelligent design community accept the general idea that the earth and its biological world is very old. Second, they accept the idea that "present species of living things have in some way descended from previous species over a very long period of time" (Griffin 2008, 271). This statement expresses the idea of macroevolution and the thesis of common ancestry. However, they call into question the sufficiency of a third key feature of Darwinian evolution: natural selection. Briefly put, natural selection filters through biological traits and "causes some genes and genetic combinations to be transmitted to the following generations with higher probability than their alternates" (Ayala 2008, 72). ID thinkers such as Stephen Meyer (Meyer 2009), Michael Behe (Behe-2006), and William Dembski (Dembski 1999) take issue with the Darwinian proposition that the "sole mechanism behind the enormous taxonomic diversity displayed by terrestrial life..." is natural selection (van Inwagen $2003_{2} \div 352$ ). One can explain some parts or even large parts of the natural order through natural selection acting on random mutations, but those who favor ID argue that natural selection come up short against certain features of the natural order. Thus, on the ID picture, some (but not all) biological phenomena require for their instantiation a Designer. ${ }^{2}$

2 Although most (if not all) ID proponents would take the Designer to be the God of the Bible, intelligent design as a thesis remains agnostic regarding the nature of the Designer. However, as Bradley Monton argues, given this agnostic stance it is a tricky affair to pin down the exact claim of intelligent design (See Monton 2009, 1146). 
Given that both creationists and intelligent design proponents think that evolutionary biology is based on a tacit adherence to naturalism, they celebrate the failure of Darwinism as a vindication against a naturalistic rejection of the supernatural. Whether evolutionary theory is intrinsically naturalistic is a matter of philosophical debate (Plantinga seems to think that it is: 2001; van Inwagen rejects this association: 2003). Nevertheless, ID proponents maintain that the explanatory deficiencies of Darwinian evolution point beyond an exclusively naturalistic understanding of reality, whereby only natural/physical causes are operating in the natural order.

Let us now turn to theistic evolution (sometimes called Evolutionary Creationism). As we can see from the name, someone who adopts this perspective suggests that there is compatibility, and perhaps even theological congruency, between the belief in a real and active God and the core claims of modern evolutionary theory/Darwinism. It is a form of theological compatibilism, and it rejects what the theistic evolutionist Howard + Van Till has dubbed episodic creationism - $_{2}$-whereby_ God occasionally suspends the laws of nature and produces events that go beyond scientific explication (Van Till 2001).

Of course, theistic evolution, like intelligent design, comes in many flavors and it contains within itself a variety of theological, philosophical, and scientific commitments. One area of disagreement among proponents of TE concerns the extent to which God is active in Creation, and whether God performs any special actions above and beyond creatio continua. For Van Till, God's activity is contained in the formative stages of Creation: nature has been gifted with ontological potentialities and there is no need for any further special divine action. $\underline{\text { I will evaluate Van Till's proposal later in this paper as a possible way of articulating natural }}$ divine causation. Denis Lamoureux seems to express something similar to Van Till when he argues that the emergence of humanity is contained within the initial act of creation (Johnson and Lamoureux 1999; Lamoureux 2008). The emergentist theologians, Philip Clayton and 
Arthur Peacocke, however, seek to preserve the language of special divine action, and they seek to achieve this by fusing divine action with a non-reductive version of naturalism

(Clayton 1997, 2004; Peacocke 1993, 2001a, 2004).

If theistic evolution is construed as an alternative to ID, does this mean that the notion of "design" is unacceptable for the theistic evolutionist? ${ }^{3}$ Those who seek to combine evolution with theism differ on this point. Van Till rejects the notion of design, preferring instead to conceptualize Creation as "optimally equipped". Denis Alexander utilizes the notion of "design" within his theology, arguing that a Christian evolutionist can perceive nature as both designed and as the product of evolutionary mechanisms (Alexander 2008). Lamoureux employs likewise the term "intelligent design" for his proposal. Del Ratzsch takes this idea further and maintains the stronger thesis that the concept of design is both scientifically legitimate and compatible with Darwinian evolution (Ratzsch 2001).

Lastly, theistic evolutionists express different beliefs when it comes to the status of naturalism within theology and whether divine action can or should be framed in terms of naturalistic categories. For Robert J. Russell, God acts in a hidden fashion through quantum events. Divine activity is objective and physically active but violates no natural law. Contrary, however, to the account under investigation in this paper, Russell maintains that divine activity should not be framed in terms of natural processes or events, for such an understanding would naturalize divine action and consequently bring God down to the level of creatures. God's transcendence would be severely undermined (Russell 2008).

For Arthur Peacocke, Philip Clayton, Deborah Haarsma, David Ray Griffin, and Mark $\underline{\text { Johnston, science mediates a naturalistic understanding of nature, which excludes }}$ supernatural invention, violations of natural law, and dualistic forms of causation within the natural. Thus, naturalism is here used as a bridge or a mediating discourse between

${ }^{3}$ Closely related to the issue of design is the question if God's guidance is logically compatible with an evolutionary emphasis on randomness. For this issue, see Woudenberg and Rothuizen-van der Steen (2015)..

Formatted: Not Superscript/ Subscript 
Darwinian evolution and Christian theism. These naturalistic proposals will be the focus of this paper as I will analyze the coherency of this naturalistic formulation of theistic evolution, and whether this can pass as a line of demarcation between theistic evolution and intelligent design.

\section{$\underline{\text { The Quest for Naturalistic Divine Causation }}$}

From this brief survey, we can see that a common line of demarcation between ID and TE is a particular form of divine action, which I call "natural divine causation" (NDC). NDC, as we will see, can be construed in a number of ways. Arthur Peacocke favors an emergentist conception of reality and stresses in opposition to episodic creationism ontological continuity within the natural order: The world is "one", and it requires no extra-natural ingredients for the realization of emergent realities and phenomena. God acts through the different levels of reality through top-down causation, in harmony with the laws of nature; not against them. It is a "layered physicalism", not a reductive one, in the sense that the fundamental levels of reality have given rise to epistemologically and ontologically irreducible higher levels of reality (Peacocke 2001a, 471-486). As per the emergentist slogan, the whole is more than the sum of its parts, and Peacocke maintains that the whole exerts causal influence on its constituent parts. On a theistic reading of emergence, the whole-part influence in natural systems and environments can be interpreted as the "holistic effect of God on the world..." (Peacocke 2006, 274). For Peacocke, a significant promise of emergence theory is that such an ontology allows for a naturalized form of special divine action as God works through and within the natural, and he further maintains that such a model of divine action is consistent with the growing view of the world as "a closed causal nexus..." (Ibid.).

Evolution is for Peacocke a "disguised friend", meaning that, contrary to some of the more hostile responses to the modern synthesis, Darwin's framework provides excellent resources 
for articulating "an immanentist understanding of God's presence" (Peacocke 2001a, 477). The united message of modern science is that there is no need to "invoke any non-natural causes" to explain reality and the workings of nature (Ibid., 472). Theology should not be in the business of seeking out gaps in the causal processes of the world, and then plugging those gaps with non-natural explanations. Indeed, "The processes revealed by the sciences, especially evolutionary biology, are in themselves God-acting-as-Creator" (Ibid., 474). Contrary to ID, there "is no need to look for God as some kind of additional factor supplementing the processes of the world" (Ibid.). God acts within natural systems, and the world itself exists within the divine life. Theologically speaking, we need to conceptualize the God-world relationship in panentheistic terms (Peacocke 2006).

Philip Clayton, another champion of "emergent theology", locates divine action within and not contrary to the natural processes of this world. In a similar way to Peacocke's layered physicalism, Clayton argues that contemporary emergence theory takes us beyond the logic of reductionism and the notion that all events can be analyzed in terms of microphysical causes. Indeed, recent advances in neuroscience casts into doubt any type of strong dualism that posits a gap between the mental and the physical, as well as those crude forms of reductionism which seek to reduce human mentality to physical events in the brain (Clayton 2000). The mind supervenes on the physical but remains irreducible to it (Clayton 2004).

This presents us not only with a non-reductionist view of the human person. A further promise of emergence is that it paves way for an immanentist and non-interventionist conception of divine action. Like Peacocke, Clayton maintains that this lands us in a panentheistic notion of God. Taking this idea further, Clayton formulated his now infamous "panentheistic analogy":

just as human consciousness (mental properties and their causal effects) can lead to changes in the physical world, so also a divine agent could bring about changes in the physical world - if this agent were related to 
the world in a way analogous to the relationship of our 'minds' to our bodies- (Clayton 1997, 258-259).

Mental causation requires no immaterial soul, nor does divine action require supernatural interruption of nature's causal workings. In this way, a modest form of naturalism can be maintained and God's action in the world can be rendered consistent with the essential claims of Darwinism.

Deborah Haarsma - the president of BioLogos - takes this idea further in a response to intelligent design theorist Stephen Meyer. Theistic evolution (or what Haarsma calls evolutionary creationism) requires no gap in the scientific picture of the world. We can, she argues, "perceive design in nature even when scientists have a complete natural explanation" (Haarsma 2017b, 222). Indeed, an evolutionary theist delights "in natural mechanisms as descriptions of the ongoing, regular activity of God in the natural world" (Ibid.). ${ }^{4}$ We need to search for natural mechanisms in the natural order and celebrate God as the author of those mechanisms (Haarsma 2017a, 132). This leads inevitably to a form of under-determinism: what the atheist perceives as purely physical mechanisms, the theist views as "God's creative handiwork" (Haarsma 2017a, 133). Thus, "God delights in working through systems..." and her form of theism accepts "that natural selection and other evolutionary mechanisms, acting over longer periods of time, eventually result in major changes in body structures" (Haarsma 2017a, 138, 139). We need to adopt an evolution-friendly account of divine action as the evidence from modern genetics "points strongly to God using the natural process of evolution to create Homo sapiens in common descent with other species" (Ibid, 111).

We find a similar ambition toward theological compatibilism in the Process theological perspectives of David Ray Griffin and Mark Johnston. According to Griffin's Whiteheadian

4 It should be noted, however, that Haarsma affirms the miraculous involvement by God in the life of Jesus Christ: "Yet evolutionary creationists also affirm that God chose at times to act supernaturally. God acts outside his usual patterns to accomplish his kingdom purposes in human history, most powerfully in the incarnation and resurrection of Jesus Christ" (Haarsma 2017a, 133). 
framework, it is the often-assumed materialistic reading of modern science and the supernaturalist assumptions of many religions - including the Christian faith - that should be blamed for creating unnecessary tensions between science and religion. On materialism, there is no subjectivity, no creativity within the natural, and no room for divine activity (Griffin 2000, 35-37). Science, on this materialistic picture, is equivalent to atheism: the mechanical view of nature "meant the total exclusion of divine influence from the world" (Griffin 2000, $\underline{41)}$.

As Griffin argues, this reductive conclusion follows from the commitment to "maximal $\underline{\text { scientific naturalism". Instead, we can and should retain a commitment to "minimal scientific }}$ naturalism", which means that supernatural causation and intervention is ruled out. Indeed, this sort of naturalism is compatible with the "most fundamental assumption of the contemporary scientific worldview" (Griffin 2000, 12), which is that "the world's most fundamental causal principles are never interrupted" (Griffin 2000, 44). Neo-Darwinism is usually construed as the antithesis of divine guidance; that, "biological evolution occurs without any theistic guidance whatsoever" (Griffin 2000, 247). This view is mistaken, and Griffin proposes instead a "wider naturalistic framework" for understanding the workings of evolution, one that allows for divine guidance within the natural. This model is, Griffin contends,

fully naturalistic. Divine influence in the world is a regular, necessary part of the normal causal process, not an occasional interruption of this process... divine influence is said to occur in basically the same way always and everywhere: by providing possible forms of actualization. The divine influence does vary in content, in that different forms are relevant for different occasions (Griffin 2000, 292).

Griffin's naturalistic process theism is, then, construed as a third possible way beyond both Neo-Darwinism (materialistically construed) and Intelligent Design. 
Mark Johnston argues likewise for a third way beyond supernaturalistic theism - the belief in "invisible spiritual agencies whose putative interventions would violate the laws of nature" - and atheistic naturalism (Johnston 2009, 40). Supernaturalism is idolatry, and "true religion" requires us to adopt a naturalistic view of reality whereby the physical is causally closed. Through a panentheistic model, Johnston stresses the ubiquitous presence of God in all natural events and processes. Johnston's God, however, should not be equated with the God of classical theism which pictures the divine as an "utterly transcendent unmoved mover, a being totally self-complete without creation..." (Johnston 2009, 119). Instead, on his process panentheism, "God is partly constituted by the natural realm, in the sense that his activity is manifest in and through natural processes alone" (Johnston 2009, 119). This theological shift means that God is no longer in the category of substance, "but in the category of activity" (Johnston 2009, 120). Given this closer identification between the natural and God, there is no need of "dabbling in the shallow and murky waters of "intelligent design' - that is, without adding a supercause to the already sufficient physical cause" (Johnston 2009, 50).

Contrary to ID, theistic evolutionists pride themselves on adhering to the full sufficiency of natural selection and other relevant evolutionary mechanisms for explaining the complexity and diversity of the natural domain. There is "no need to postulate any special action" of God to account for the workings of nature; that is, a form of divine action that transcends natural causation (Peacocke 2001b, 83). God works solely through natural processes in an immanent and non-interventionist fashion. Indeed, as Clayton also puts it, this account of God's ongoing activity denies any "qualitative or ontological difference between the regularity of natural laws conceived as expressing the regular or repetitive operation of divine agency and the intentionality of special divine actions" (Clayton 2004, 84). In a previous article, XXXX and I termed this ontological move in the divine action discussion Natural Divine Causation (NDC). 
Those who opt for NDC suggest that "a particular event, $E$, must be causally attributed to God's influence, $G$, and natural causation, $N$. That is $G$ and $N$ both (fully) explain $E$, as God only acts from within natural processes" (XXXX and XXXX). In this way, the interventionist supernaturalism of ID can be avoided. NDC provides a way in this discussion to demarcate theistic evolution from the claims of ID, and a model for picturing God's interaction with reality that is consistent with Darwinian evolution.

\section{NDC and the Challenge from Causal Overdetermination}

At first glance, NDC seems to offer a viable alternative for those who want to maintain the completeness of Darwinian evolution and the full sufficiency of natural selection, whilst affirming the sustaining and providential action of God. NDC paves way for not only a noninterventionist model for divine action, but it shows how Christians (and other theists) can consistently regard evolution as a "disguised friend".

Yet, NDC as a causal model for God's continuous guidance of the evolutionary unfolding of nature seems muddled and obscure. NDC represents a form of theological compatibilism, in the way that it stresses the coherency of holding together in ontological unity the purposeful activity of God and the mechanisms of evolutionary theory. I want to critique this form of compatibilism. I will draw here on some key issues in philosophy of mind regarding the issue of compatibilism between what might loosely be called "psychological explanations" and "mechanistic explanations". The question we will investigate is, is it philosophically coherent to have "multiple explanations of a single explanandum"? (Kim 1993, 238).

A theist stresses that God brought humanity into existence: "God has created the world and it therefore exists for a reason, and God has also a special plan with the creation of human 
beings" (Stenmark 2012, 550). This is a teleological view of humanity as it holds that human existence is "not due entirely to chance and randomness" (Ibid., 551). A theistic explanation for why there is such things as human creatures involve "psychological" or "agential notions"; meaning that the instantiation of humanity is explanatorily connected to the intention and desire of God. This is true regardless of whether one opts for a special creation account - which holds that humanity and all life on Earth originated in its present form - or if one affirms the NDC idea that God created humanity through the mechanism of natural selection and other evolutionary forces over a long period of time.

In a compatibilist spirit, the proponents of NDC argue that we can, and indeed should, hold together agential/psychological explanations (i.e. divine intentionality) with mechanistic explanations (i.e. explanations through evolutionary mechanisms). But, is this possible? Philosopher Jaegwon Kim has critiqued such epistemic compatibilism in the arena of philosophy of mind, most clearly articulated in what he calls the explanatory or causal “exclusion principle" (Kim 1993; 1998; 2005). This principle states that two explanations cannot independently and sufficiently account for the same event or phenomena. A robust explanatory realism cannot posit explanations $E^{I}$ and $E^{2}$ as sufficient explanations for a single event. Based on epistemic simplicity either $E^{l}$ or $E^{2}$ must go, otherwise we end up with the philosophical problem of overdetermination whereby we posit more causes than necessary for the event in question. If Peacocke, Clayton, Haarsma, Griffin, and Johnston argue that divine causation and natural processes are both sufficient causes for, in this case, the creation of humanity then this form of theological compatibilism seems to invite the problem of overdetermination. Thus, the problems that Kim has explored within philosophy of mind through the causal exclusion principle seem to be equally present within the theological area of divine action. 
NDC pictures a strong ontic relation between $G$ and $N$, and this does not allow for an innocent form of overdetermination. How should we more precisely understand this relationship? One way to understand NDC is through the philosophical theory of "supervenience". Roughly speaking, the theory of supervenience suggests that higher-level property $P$ supervenes on physical base $B$, in the sense that any event at $P$ must correspond to an event at $B$ (Kim 1993). Per the supervenience slogan: No higher-level difference without a physical difference. With regard to the issue before us, we can construe the NDC claim as to be saying that divine activity - as it must always be mediated through natural processes supervenes and depend on a natural base level. Thus, in order for $G$ to produce $E$ there needs to be a corresponding happening at natural base level, $N$. Indeed, in a previous exchange with $\mathrm{XXX}$ and $\mathrm{XXX}$, they seemed to be claiming something along those lines in their defense of Amos Yong's emergentist articulation of Pentecostal theology. As I and XXX argued in a response to XXX and XXX, such employment of supervenience and application on matters of divine action carry problematic consequences. Supervenience is a technical concept and difficult to grasp, but it can be formulated in a weaker and stronger version. In its weaker form, and applied on NDC, this model would say that $G$ supervenes on $N$ in the sense that divine activity within the natural order could not occur without some mediation by the mechanisms of evolution. There is ontological dependency between divine action and natural processes. On a stronger version, lower levels fix the events at the higher levels, meaning that there is a relationship of determinism between the two. NDC based on either weak or strong supervenience undermines the causal efficacy of divine influence as, given the theory of supervenience, whatever happens on a higher level is already contained at the base level. That is, the causal contributions of God are already present at the physical level, but this means, as Kim explains with regard to the issue of mentality depending on the physical, that supervenience invites epiphenomenalism (Kim 2006, 557-559). It would lead to 
epiphenomenalism as it is unclear on NDC to what extent divine influence adds anything causally to our understanding of the natural order. If $G$ depends on $N$ in such a way that the causal contributions of $G$ are already contained in $N$ then the causal contributions of $G$ seem epiphenomenal. If NDC is articulated through supervenience, then God's ongoing activity within the natural is rendered vacuous and ontologically superfluous. If this is the case, the ID critique of TE seems to be correct that TE has unwittingly embraced a fully secular model of evolution.

Perhaps these proponents maintain something stronger? They might mean that on NDC there is no ontological difference or distinction to be made between divine causality and natural causation. On this stronger view, it is not possible to distinguish divine influence or action from those processes under investigation in the natural sciences (although, it might be possible to maintain a linguistic difference between God's influence and natural processes). On this view, $G$ and $N$ somehow constitute each other; divine causation and natural causation "are mutually dependent upon one another for both their ontological existence and effectiveness" (XXXX and XXXX, 263). This ontological move could easily avoid Kim's overdetermination problem, but the obvious risk is that it makes divine action, or God-talk, ontologically superfluous. Indeed, by simply equating divine activity with natural events "there would no longer be any reason to interpret it [an effect in the world] as an instance of divine action" (Clayton 2004, 193). We would no longer have any reason to invoke theological explanations in our epistemic pursuits. -Again, those who worry that theistic evolution invites deism might be somewhat justified if NDC interpreted in this way forms the basis for a theistic accommodation of evolution.

If NDC faces significant issues, and cannot be accounted for in terms of supervenience, perhaps one can understand the relationship between divine causation and natural causation in terms of what in philosephy of mind has come to be called double aspect monism. This monism 
seeks to steer a path between materialism and dualism by stating that the mental and physieat are not distinct ontological categories, but rather two aspects of the same underlying substance. Thus, its defenders understand it as a monistic alternative in the body mind debate as this via media refrains from unnecessarily multiplying ontelogical categeries. For Jirir Benovsky, whe embraces this monism, the physical and the mental are not two distinct properties; rather, they are "two different aspects of one and the same metaphysical reality" (Benovsky 2018, 15). The physical aspect is incomplete as a perspective on reality, "but so is the subjective perspective" (Ibid., 16). Indeed, "Both are needed, and one is not more relevant than the other" (Ibid.). Given especially Clayton's and Peacocke's commitments to monism, a double-aspect interpretation of NDC is not far away. As Clayton states with regard to emergence theory: "Reality is ultimately composed of one basic kind of 'stuff"' (Clayton 2006: 2). If we apply such monism on NDC we might say that $G$ and $N$ can be understood as two aspects of "one kind of "stuff". On a double aspect perspective, divine influence and the processes of evolution are not construed as two ontologically distinct causes, and so this way of formulating the idea of natural divine causation might be able to bypass the problem of causal exclusion (or epistemic simplicity in general). In this way, the general framework and logic of NDC can be upheld, and it can still function as a line of demarcation between theistic evolution and intelligent design. A dual aspect view, although interesting in and of itself, raises a number of issues for those who seek to articulate God's ongoing influence within the world through NDC. How should we understand the realness or ontological status of the divine and natural "aspects" of the world? Are they irreducible to one another, and do they have stronger ontological independence, existing in some way above and beyond their underlying substrate? If interpreted in a strong sense, a thicker notion of ontological irreducibility would go badly with the monistic commitment of NDC, and TE would be pushed towards the dualism of ID. If 
interpreted in a weaker way, this monism might push TE closer to pantheism in virtue of eollapsing divine transcendence into the physical.

One could, however, interpret this double aspect view in a slightly weaker sense and say that, while there is no ontological distinction to be made between the divine and natural aspects of this monistic world, one can still maintain a conceptual distinction between these two aspects; aspects which could both be described as causing an event. Depending on one's conceptual framework, it is possible to either understand $E$ as the product of divine guidance or through the natural mechanisms of evolution. There is no correct ontological view, merely different language games or conceptual standpoints. This conceptual interpretation, however, comes across as too weak given that our understanding of the world and our theological ambitions to understand nature is reduced to mere linguistic and social convention. Indeed, for those who support the framework of NDC, and who seek to understand how an ontologically real God interacts with nature and humanity, a linguistic understanding of divine activity would not be sufficient.

A double aspect view of NDC raises another important issue, pertaining to causality. What does it mean to say that an aspect of an ontological-substrate is causally responsible for something? Can an "aspect", whether it be divine or natural, cause anything? This is not meant as a defeating critique of a double aspect view, but its defenders need to clarify the causat aspect of this approach. This lack of clarification means that NDC should not be articulated in terms of, or in parallel with, a double-aspect view of consciousness and its relationship with the physical. If we are seeking a line of demarcation between theistic evolution and intelligent design, a double-aspect interpretation of NDC does not seem to offer the adequate ontological tools. 


\section{Partial Causation and the Dilemma for Theistic Evolution}

Another, more promising, way of understanding NDC is in terms of what might be called "partial causation". This means that neither $G$ nor $N$ is explanatorily sufficient to explain the coming into being of humanity $(H)$, instead we need to invoke both factors for explaining why there are such things as complex human creatures. Kim explains partial causation in this way: "we might explain why an automobile accident occurred by citing, say, the congested traffic, or the icy road, or the faulty brakes, or the driver's inexperience, etc. depending on the explanatory context, even though each of these conditions played an essential role in causing the accident" (Kim 1993, 251). This causal picture does not involve two complete explanations for one event, but it aligns itself with a common assumption in many human practices, namely that we need to invoke several factors to explain a range of phenomena. The promise of this approach is that we would avoid the problem of overdetermination. Another way of framing this is through the "dual explanandum strategy" (Kim 1991, 293-294). As a response to the problem of overdetermination within philosophy of mind, this strategy urges us to think of physical explanations and mental explanations as separate and autonomous causal lines that explain different properties of the same effect. Applied on the issue of NDC, we can imagine divine activity, $G$, and natural causation, $N$, being causally relevant to different aspects, properties, or features of the explanandum; hence, there is no epistemic competition. Although certainly more coherent, the idea of partial causation, or dual explanandum, is too dualistic for the NDC proponent, since partial causation posits two distinct and irreducible causes. That is, if $G$ makes a causal contribution to $H$ that is not reducible to $N$ then $N$ alone is insufficient for explaining $H$, in the same way as $G$ alone would be insufficient (XXXX and $\mathrm{XXXXX).} \mathrm{This}$ means then that natural processes alone and the mechanisms of evolution are insufficient for explaining $H$, and that we need to supplement our explanatory framework with non-natural factors and perhaps even a theological dimension. This would pull theistic evolution closer to 
the anti-naturalistic assertions of intelligent design, as the claim would now be that natural selection and other evolutionary forces are insufficient for explaining the emergence of humanity. If theistic evolutionists were to explicate NDC along the lines of partial causation, then the boundary between theistic evolution and intelligent design would be blurred, as they would now both concede the limits of Darwinian evolution for explaining why there are human creatures. This move towards partial causation would go against, for example, Haarsma's compatibilist proposal which urges us to think of divine action as fully consistent with the completeness of naturalistic explanations. There remains here an ontological distinction that goes against the ambitions of those scholars who opt for NDC as the way forward in the science-religion debate, and against those who maintain that NDC might function as a line of demarcation between theistic evolution and intelligent design.

Those who embrace NDC, and who emphasize God's immanent influence within the natural in order to establish a line between theistic evolution and intelligent design, face a dilemma: a) NDC in a strong form entails causal overdetermination and makes God-talk superfluous, b) NDC can avoid overdetermination by picturing $G$ and $N$ as partial causes, perhaps belonging to the same causal chain, but c) the idea of partial causation is too dualistic and hence incompatible with the ontological claims of NDC. In this way, NDC cannot serve as a demarcation line between theistic evolution and intelligent design. Unless the theistic evolutionist wants to make God-talk superfluous, this type of theist needs to reject NDC as a proper formulation of divine action. Yet, if the theistic evolutionist were to reject NDC, then it is conceded that natural causes and evolutionary mechanisms are explanatorily insufficient. In this way, it becomes much more difficult to distinguish theistic evolution from the core claims of intelligent design, at least with regard to the issue of explaining humanity in a natural world.

I believe that partial causation is the best way to frame the theological and philosophical claims of theistic evolution, and it is important to understand the metaphysical implications for 
science of such a view. On this view, if God accomplished a particular effect by means of natural causation, then we need to appeal to both divine activity and natural processes to account for the effect in question. Both bring something ontological to the picture. This means,

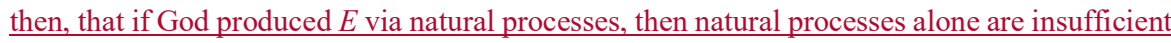
to explain $E$. This is not to downplay the explanatory significance of science. Rather, it is to emphasize the explanatory value of both theology and science. As I argued for in a previous paper with regard to the naturalistic models of divine action proposed by panentheists: "God must be allowed to make a causal difference in reality, and for this to be possible there needs to be some qualitative/ontological difference between God's influence and natural laws. Of course, this would imply that from a theistic perspective, scientific causal explanations will always be incomplete" (XXXX). This implication has also been highlighted by Keith Ward: "If God's intentions plus the physical laws do give a sufficient explanation of what happens in the world, whereas the physical laws do not, it is clear that the existence of God contributes substantially to an explanation of what happens in the world" (Ward 2007, 79). ${ }^{5}$ Given this model of partial causation, we can make sense of God acting through natural processes, in comparison to NDC which makes God-talk superfluous and reducible to naturalistic categories.

\section{Possible responses and reformulations of NDC}

NDC faces significant problems, but it is premature to rule it out as a suitable line of demarcation between TE and ID. There are four three strategies, currently employed in the

\footnotetext{
5 This assertion raises the much feared "God of the Gaps problem". Broadly speaking, those who reject the notion that God acts directly in nature fear that the interventionist view of God entails the fallacy of the "God of the Gaps", whereby one takes gaps in science as evidence of divine intervention. This is the fallacy of "argumentum ad ignorantiam, i.e., an appeal to ignorance" (Larmer 2002, 129). However, as Robert Larmer argues, those who argue for specific cases of divine intervention within the natural do not typically do so only on the basis of ignorance; indeed, they often make positive arguments for divine agency based on what we know and the probability of something occurring in the presence of only natural causes.
}

Formatted: Not Superscript/ Subscript

Formatted: Indent: First line: $0 \mathrm{~cm}$ 
literature, for retaining the general model of NDC. If one of these can be employed by theistic

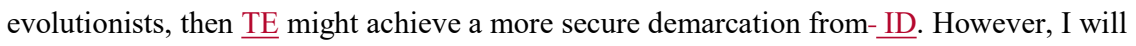
show that these too face significant challenges. The first strategy that I want to look at attacks the heart of the argument against NDC; namely, overdetermination. It has been argued that there are "innocent cases of overdetermination", which, if true, would undermine the force of my case against NDC. The second strategy utilizes a Thomist view of divine action in terms of the much used model of "double agency". The third strategy argues for the coherency of NDC based on Van Till's view of Creation as "gifted". The fourth and last way of defending NDC is to appeal to the pragmatic necessity of NDC for defending the continuous functioning of modern science - and thus NDC would be the only scientifically responsible way to imagine divine action.

Formatted: Font: Not Italic

\section{Causal overdetermination: No Problem!}

The NDC proponent might respond to the critique made above by saying that overdetermination is not necessarily a problem. Are there not genuine cases of overdetermination, such that causes $C_{\AA}^{1}$ and $C_{\perp}^{2}$ intersect at a common event without one undermining the other? Imagine two assassins, both firing an arrow and simultaneously fatally Formatted: Superscript Formatted: Superscript hitting their target. In this case, being struck by one arrow is sufficient to account for the event, i.e. the death of the victim. We have then a case of overdetermination, in the sense that each assassin's arrow belongs to the causal ancestry of the victim's death. It would then be wrong to claim that either of these causal happenings are ontologically redundant. Both assassins would be in some way causally and morally responsible for the outcome. Is it not possible to $\underline{\text { say something similar on behalf of the relationship between divine action and natural causation }}$ as it is portrayed by the NDC proponents? Can NDC be framed as an innocent form of overdetermination? Although plenty of philosophers believe that there are genuine cases of 
overdetermination, such belief can be called into question. Drawing on Martin Bunzl (1979), we might say that the causal contributions of Assassin ${ }^{1}$ is redundant because had Assassin ${ }^{1}$ not killed the victim, Assassin ${ }^{2}$ would have - and vice versa. Thus, both Assassin. ${ }^{1}$ and Assassin?

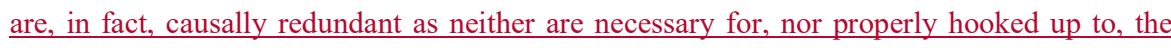
Formatted: Superscript Formatted: Superscript effect. As Bunzel intends, this is clearly an absurd conclusion. Bunzl goes on to explain that classic cases of overdetermination, when closer scrutinized, turn out to be either cases of joint causation or causal pre-emption, whereby $C_{C}^{l}$ instantiates the effect before $C_{\text {. }}^{2}$.

If such philosophical considerations are correct, then this would carry some negative implications for the theory of natural divine causation. That is, if we say that both divine Formatted: Font: Italic Formatted: Superscript Formatted: Font: Italic Formatted: Superscript activity, $G$, and natural regularities, $N$, both sufficiently produced $E$, then neither $G$ nor $N$ is explanatorily necessary for $E$. $E$ would have obtained in the absence $G$ and in the presence of $\underline{N}$, or in the absence of $N$ and in the presence of $G$. Depending on how one looks at the situation, either $G$ or $N$ would be redundant. Given that some NDC proponents, such as Clayton, rely on a counterfactual principle for evaluating theories of divine action, this implication should be unacceptable. For Clayton, this principle means that "had God not acted in helping to produce some effect, the effect would not have been identical to the state of affairs we in fact observe" (Clayton 2008, 104). The problem, here, is that it is unclear on NDC to what extent divine activity contributes anything causally to the world. In order to avoid this dilemma, one needs to show that NDC can be a genuine case of overdetermination.

Even if one affirms that there are genuine cases of overdetermination, it should be noted that the assassin-case entails a picture of two separate and independent causal chains that, unfortunately for the victim, intersect at the same effect. This scenario is not, then, perfectly analogous to NDC given that this naturalistic model of divine action seems to maintain something stronger than the idea that two distinct causal chains coincide at $t$ to produce $E$. NDC claims rather that $G$ and $N$ belong to the same causal chain as this model denies any form of 
dualism within the natural order, as well as any ontological separation between divine influence and the regularities of nature (Peacocke 2004, 9).

In the standard case of overdetermination, such as that of the two assassins, we have two independent causes that are individually sufficient "and hence individually unnecessary" (Moore 2012, 325). This is what Moore calls "independent overdetermination" (Moore 2012). In philosophy of mind, nonreductive physicalists typically argue for the idea that the mental supervenes on the physical and is necessarily brought about by the physical. On this picture, the mental and the physical are not independent of one another (Lower 2002 stresses this point). The mental depends on the physical and is entailed by the properties and configurations of the physical level. As Moore goes on to explain, this "is clearly a different sort of overdetermination than independent overdetermination" (Moore 2012, 324). If we look at the discussion regarding natural divine causation, we can say given this model of "dependent overdetermination" that if God, $G$, causes $E$, then the divine act is necessarily mediated by some physical mechanism, $P$. Thus, $G$ and $P$ do not independently and sufficiently cause $E-$ an idea which encounters the causal exclusion problem - but given that God only acts through and within the natural, $P$ will be accompanied by every act of $G$. $P$ would be a necessary feature of God's activity within the natural. However, this amounts to a very strong claim that proves difficult to justify. We can surely imagine a world in which God accomplishes certain purposes within the natural order in a non-physical manner. Indeed, some of the strongest supporters of NDC admit that God can perform actions supernaturally - most Christians would want to point at Jesus's resurrection as one such supernatural event. Thus, this way of framing NDC through "dependent overdetermination" is too strong.

Even if one frames divine action as intrinsically tied up with natural processes, this account entails a problematic dualism that is incompatible with the idea of natural divine causation. If God produces $E$ via $P$, then $P$ alone is explanatorily inadequate with regard to $E$. That is, had 
God not willed $E$ then $E$ would not have obtained, but this conclusion goes against the NDC ambition to uphold the completeness of the naturalistic story. Remember that for Clayton, $\underline{\text { Haarsma, Griffin, Johnston, and Peacocke, natural processes are explanatorily sufficient to }}$ account for events within the natural world. Yet, if $E$ has its causal origin in divine agency, then this is tantamount to admitting that natural processes alone are insufficient for explaining $\underline{E}$

\section{Agnostic Naturalism}

Colin McGinn's agnostic naturalism is a response to the mind-body problem. We have reductionist, physicalist, dualist, neutral monist answers to the enigma of conseiousness, and none of them, argues McGinn, can do justice to or fully explain how it is that neurological firings in the brain can produce consciousness or the richness of subjective experiences. MeGinn suggests not merely that contemporary solutions to the mind body problem are explanatorily inadequate, and that a future solution is still possible. To the contrary, MeGinn maintains that this problem is unsolvable given that the real solution is mavailable to eognitive creatures like us. He says the following about this issue: "Minds are biologicat products like bodies, and like bodies they come in different shapes and sizes, more or less eapacious, more or less suited to certain cognitive tasks" (McGinn 1989, 350).

Given that human beings are not cognitively equipped to deal with a problem of such magnitude, it is not surprising, according to McGinn, that all constructive attempts to explain the nature of human mentality have fallen short. Indeed, there is very little agreement between philosophers as to what kind of explanations to pursue, or how to define consciousness. We should, however, not venture into anti-realism and dismiss the body-mind problem as illusory, or declare the emergence of consciousness as miraculous. McGinn's propesal is a non constructive selution, which means that we can appreciate a problem 
without being able to solve it. MeGinn writes: "... I think it is undeniable that it must be in virtue of some natural property of the brain that organisms are conscious. There must be some explanation for how brains subserve minds" (McGinn 1989: 353). Agnostic naturatism maintains that there is a natural or physical solution to the body mind problem, but unfortunately this is not accessible to human creatures with limited cognitive resources. In this way, MeGinn hopes to safeguard a general naturalistic ontology while recognizing the mysteriousness of consciousness.

If we apply McGinn's non-constructive solution and agnostic logic to the problem of divine action, and the problem of making philosophical sense of NDC, we might say something like this: "Human beings are not cognitively equipped to explain how God creates through natural processes without encountering the issue of overdetermination, but God does so and there is an explanation". This could be one way of defending NDC without explaining NDC, or trying to solve the problems that I have pesed against the idea of natural divine eausation. That is, one would be able to hold to a naturalistic view of divine causality, without being able to explain how God creates naturally. In this way, one can-still hold to NDC as a suitable demarcation line between TE and $\mathrm{ID}$.

Before evaluating this solution, it should be noted that a general agnosticism regarding divine causality is neither uncemmon nor antithetical to Christian theology. In fact, proponents of what is called apophatic theology - which has a long history in Christian theology - tend to express some level of agnosticism regarding divine nature and will for the main reason that God's infinite nature is beyond human understanding.

However, this strategy, I think, should not be appealing to the supporters of NDC, and particularly those scholars committed to interdisciplinary theology. To adopt a thoroughly agnostic approach to divine action would halt and undermine the dialogue between theology and-science, because relegating divine action to the realm of the mysterious would undercut 
the interdisciplinary aim of many science religion scholars. Hence, for these who value and purste an interdisciplinary approach to theology, an agnostic strategy will not be very eompelling.

A secend reasen for doubting this agnestic defence is that if we are too agnestic regarding divine action, then a proponent of the NDC account will lack justification for the claim that God only works through natural processes. Such agnosticism will, moreover, open the back door for divine intervention and Intelligent Design; if we cannot explain how God works through purely natural processes, then it is fair game for the ID supporter to claim that God produces events supernaturally by overriding the mechanisms of evolution.

\section{Non-competitive Transeendence}

Intelligent design maintains that certain biological features are not reducible to natural configurations, or unguided interactions between material entities, and that it is justifiable to infer design from such phenomena. A theological worry in this discussion is that ID reduces God to a designer, someone who-ccasionally meddles with the causal makeup of the universe, undermining the integrity of the workings of nature. God becomes merely a cause among other eauses, or merely one agent in the greater scheme of things. As Robin Parry, in a blog post at the website for BioLogos, nicely puts it: "The problem here is that the 'designer' which almost every ID advocate thinks is the biblical God - is pictured as one being among others (albeit a more intelligent and powerful one) acting as a cause in the world in the same manner as other causes acts in the world" (Parry 2017). This is the main theological error of ID; it places God at the level of creatures, and God acts in the same (or at least very similar) causal manner as human creatures. God is thus on the same level as human agents. As John Haught similarly claims, "To introduce ideas about God or intelligence as the direct 'cause' of design would be theologically as well as scientifically ruinous" (Haught 2007, 237). 
NDC provides for the theistic evolutionist resources for avoiding the "ID error" of bringing God down to a creaturely level. God acts "indirectly" through and within natural processes in a co-operative way, in conjunction with and not against the forces of evolution. The proponent of NDC might say that God acts in a different cattsal manner, compared to the forms of causality that we are familiar with. God works naturally throughout the physical, but in a different causal manner or perhaps even in a non-causal manner. This strategy stresses the otherness of divine causality, as well as the non-competitive relationship between divine will and the regularities of the physical. A person who frames NDC in this sort of way would say either (a) God is not a person like us, thus God does not act in a causal manner similar to humans; or (b) God is a person like us, but given God's supreme nature we should expect divine eatusality to be radically different to human causality.

(a) and (b), although different to each other, both imply that divine causality is sui generis and different to all other forms of causality. The overall logic of (a) and (b) is that given the difference between the Creator and the created it is ill advised to articulate divine causality through the types of causality that we encounter in the created world. One could then say, in favor of the NDC account, that the outlined causal exclusion argument does not affect the plausibility of natural divine causation, because God, while only acting through natural processes, operate with a very different form of causality. If NDC can be maintained in this way, then we can uphold a distinction between theistic evolution and intelligent design.

I am somewhat sympathetic to this approach to divine action and way of defending the sui generis character of God's involvement in the natural and in the lives of human beings, but I do not think that a defense of NDC based on such causal presuppositions is successful. The first problem is that it pushes our ambition to spell out the details of divine action into-sheer agnosticism. This is because, if the gap between the Creator and created is too great, then we eannot know or say anything with confidence about God's involvement in the world. And if 
we cannot say anything positively about God's presence, then we are left with an agnosticism which jeopardizes our attempts at making progress in the divine action discussion. This would be a disastrous consequence for the divine action debate in particular, and for theology in generat.

The problem is more acute for NDC proponents. If we adopt a notion of causality that departs radically from these forms of causality that we are familiar with, then it becomes impessible to specify how God acts in creation; therefore, one cannot coherently claim that God works enly through natural processes. Indeed, if we cannot say that God only works through the natural, then it leaves open the possibility for an ID defender to claim that God, at certain points in natural history, has acted in an interventionist manner by directly causing and designing particular features of the world. An approach that stresses divine transcendence and otherness can potentially dodge the causal exclusion problem, but the downside of this propesal is that it ends up introducing a streng form of agnosticism that undermines the interdisciplinary ambition of the many supporters of NDC, as well as the naturalistic underpinning of this model for God's action and presence.

\section{NDC as naturalistically tinged Thomism?}

Given that NDC proponents seek to preserve the integrity of the natural world (in the sense that its daily functioning does not depend on supernatural interventions), maybe it would be fruitful to consider this model of divine action as a naturalistic accommodation of Thomism? What is the Thomistic conception of divine action? As Ignacio Silva helpfully explains, Thomas Aquinas's view on divine action can be summarized with four principles, "1) God's omnipotence and transcendence": God can do anything that is logically possible. "2) God's providential action": God not merely sustains the world, but acts in it. "3) the autonomy of natural causes": nature requires no extra-natural intervention. "4) the success of reason and 
science": Science, and reason more broadly, can investigate the world empirically and offer naturalistic explanations for nature and its activities (Silva 2016, 66). The promise of Thomism, according to Silva, is that it can successfully hold together these principles: "Aquinas's doctrine, thus accounts for an autonomous natural causality that, at the same time, depends completely on God's causal powers" (Silva 2014, 285).

The Thomist argues on this model of double agency that God "acts in and through natural causes" and moves "created causes to cause" (Silva 2016, 66). So far, this sounds very similar to NDC and it could provide a way beyond Intelligent Design. Thomism and NDC, however, $\underline{\text { seems to differ on a substantial issue. For a Thomist, "God and the natural agents act on two }}$ different levels" and "God and the evolutionary process are not on the same "level"" (Silva 2016, 73, 77). This sounds too dualistic for NDC. Moreover, on this Thomistic view of divine action "God gives the power, sustains the power, applies the power to cause, and achieves effects which go beyond that natural power" (Silva 2016, 82; Cf. Silva 2014, 282). The latter assertion seems, also, too supernatural for NDC as the divine effect exceeds the natural powers of the agent.

While this section merely seeks to test the compatibility between Thomism and NDC - and not as a rejection of a Thomistic view of divine action per se - I want to suggest that Thomism seemingly faces a similar overdetermination problem to NDC. Silva is clear on the fact that on Thomism “...God acts as a sufficient cause" (Silva 2016, 73). God acts perfectly as first cause of all events, and "everything that the secondary cause is and does is caused by the primary cause" (Silva 2014, 280). Nevertheless, in order to avoid the occasionalist entailment, the Thomist simply "holds that the secondary (or instrumental) cause determines the particular effect achieved by the action of the primary cause" (Silva 2016,73). The secondary cause is always, and necessarily involved, in the causal chain. 
Silva seems to make two claims in favor of this compatibilism, explaining why the secondary cause is not redundant despite God being a sufficient cause: 1) God wishes to perform actions through creatures, and so creatures are part and parcel of the causal chain. 2 ) The secondary cause determines the effect in the sense that the effect of the divine act will manifest itself in a manner according to the telos of the natural agent (Silva 2016, 74). Both claims fail to address the overdetermination problem. (1) Simply states that natural agents belong to the causal chain, without explaining how natural agents can causally contribute to $E$ when $E$ is sufficiently caused by God. (2), on the other hand, seems to confuse what might be called ontological constraints with causal efficacy. It might be the case, as is claimed on (2), that the manifestation of the divine will is constrained by the ontological makeup of the natural agent; the causal power "of the secondary cause is that which determines the production of this effect" (Silva 2014, 283). Nevertheless, this is different from the claim that the natural agent is contributing causally to the effect, and that the secondary cause is contributing to the world in a causal manner. The implication would seem to be that human agents (or any other creature) do not act or do anything, instead they only constrain God's will and activity. Hence, (2) does not tell us how a natural agent can be causally efficacious or participate in a causal chain that is already sufficiently authored by God. In light of this issue, some Thomists simply state that the issue of how God "directs the actions of creatures through different modes of causalities... is part of the mystery of creation..." (Austriaco 2003, 963. See also Austin Farrer's more agnostic formulation of double agency, 1967).

To round this section off: Since Thomism relies on a strong theological and causal dualism, NDC should not be construed as a naturalistic version of Thomism. Indeed, Thomism itself seems to face something akin to the overdetermination problem, and so offers no relief to theistic evolutionists who seek to go beyond intelligent design through NDC. 


\section{The "Gifted Creation" approach to NDC}

Given that Thomism makes an ontological distinction between primary and secondary causation, with God and natural agents acting on different ontological levels, this model for divine action is incompatible with the overall logic of NDC. One way of preserving NDC, and hence the "completeness of the natural", is to locate divine action solely in primary causation. This formulation of NDC brings us back to Howard Van Till's theological vision of the "Gifted Creation". According to Van Till's divine action model, we need to start with a "formational economy of the universe", by which he means the "set of all dynamic capabilities of matter and material, physical, and biotic systems that contribute to the actualization of both inanimate structures and biotic forms in the course of the universe's formational history" (Van Till 2001, 493). No divine intervention is necessary with regard to the "daily functioning" of the universe. Van Till recognizes that there are "epistemological gaps" in the scientific story about the world, but we should not commit the creationist/ID error of positing supernatural explanations or invoking extra-natural ingredients in order to address these gaps or anomalies. Instead, God has gifted creation both with a "rich potentiality space" and the "capabilities for realizing these potentialities by means of selforganization..." (Van Till 2001, 508). The universe is, hence, "astoundingly robust and gapless" (Van Till 2001, 508). God's action in this gapless world is manifested in the divine calling upon creation to employ or actualize its natural abilities. Divine providence is not distinct from creation (Stek 1990, 246), and we need to consider secondary causation as already contained in primary causation. There is no need to appeal to special divine action to account for natural phenomena (Ffor a similar account to Van Till, see Knight 2009). Given its rich ontological resources, creation will produce novel phenomena over longer periods of time, through the interplay of chance, randomness, and various evolutionary mechanisms and 
factors. This could be one way of framing the compatibility thesis which the NDC adherent strives to uphold in opposition to the "gappy" account of ID.

Van Till's theological model can be interpreted in a stronger and weaker form, both facing $\underline{\text { significant challenges. If we understand this view of divine activity in a stronger fashion, God }}$ would have set up the universe and its unfolding in a deterministic fashion. Like that of the relationship between a programmer and a software, God simply programmed the universe to produce certain things according to its own potentialities. While this model would make the world insulated from any additional supernatural interventions it seems, however, to entail a problematic determinism which, subsequently, undermines the causal efficacy of natural agents - including human creatures. If the universe is theistically determined, then how could human agents contribute anything to the world? As Alston has commented with regard to the cost of a similar deterministic proposal: "The price of this would be not only an acceptance of complete determinism but also the inability to treat some events and not others as acts of

God" (Alston 1994, 58). This may have severe consequences for Christian notions of special revelation. This view has no room for libertarian agency which would contradict, in particular, the ambitions of Peacocke and Clayton to articulate human agency through emergence theory. Although I do not have the space to develop this second concern, such determinism would also render acute the problem of evil. God would be responsible for all natural events on this model, including natural evils and moral evils. This is not to say that this model is prima facie implausible, but it does produce some significant theological costs and concerns.

On a softer reading of Van Till's model, the universe is not pre-programmed in a deterministic fashion, but God "acts by calling upon the creation to employ its creaturely capabilities to bring about a fruitful outcome..." (Van Till 2001, 509). This would avoid the strict occasionalism of the stronger reading. Yet, depending on how one interprets the phrase 
"calling upon", this idea seems to go against the logic of NDC and the ambition to avoid any ontological distinction between divine activity and natural processes. If this statement entails

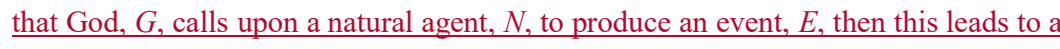
dualistic picture, whereby God makes a causal contribution to $E$ that is not reducible to any natural process. $G$ produces $E$ via $N$; nevertheless, this means that $N$ is explanatorily insufficient for explaining $E$. If one maintained, however, that $E$ would have occurred regardless of $G$, then one is making divine activity explanatorily superfluous. The naturalistic story would in this way be complete, and there would no longer be any reason to invoke a $\underline{\text { theological or theistic framework for understanding the world. This would, indeed, be to }}$ sacrifice faith at the altar of naturalism. In the end, this articulation of NDC cannot function as a line of demarcation between theistic evolution and intelligent design.

\section{A pragmatic defence of NDC}

The last defense is more pragmatic in nature. It does not claim that God cannot intervene in reality, and that the ID assertion that God sometimes acts in an interventionist manner is necessarily false. Rather, this argument is concerned that the notion of an "interventionist God" undermines the practice and rationality of modern science. According to Clayton, we need to base our epistemic projects on the "presumption of naturalism", meaning that "for any event in the natural world, that its cause is a natural one as opposed to a supernatural one" (Clayton 1997, 171). If we do not assume this naturalistic view, "science as we know it would be impossible. Scientific activity presupposes that causal histories are reconstructible in principle, which they would not be if the cause of some specific phenomenon lay outside the natural order altogether" (Clayton 2004, 163).

A pragmatic defense of NDC states that we need to articulate divine action in such a way that it can be rendered consistent with the naturalistic assumption that "the world's most 
fundamental causal principles are never interrupted" (Griffin 200ํt, 44). Such a defense admits that it is logically possible for God to intervene in reality, it is God's creation after all. Nevertheless, such interventions would undermine the rationality of science. Scientists must assume in their work that reality is predictable - at least to a great extent. However, if God were to intervene, then the world becomes irregular and perhaps even chaotic. Science, we are told, would be impossible in such an interventionist world, as God directly causing and bringing about certain outcomes would make reality unpredictable. In this way, a theist who values modern science needs to account for divine action in non-interventionist and naturalistic terms, and this makes ID unacceptable as it invokes non-physical categories to explain physical features. Regardless of the causal problems facing NDC, this pragmatic argument says that we still need something like NDC in order to uphold the general reliability and epistemic value of modern science.

This argument seems rather strange and it makes some drastic leaps. It might be the case that some happenings in the universe are causally inexplicable (or inexplicable in terms of scientific categories), but that does not mean that reality in its entirety becomes unpredictable and wholly chaotic. Some degree of unpredictability should not lead us to conclude that reality as a whole is unpredictable. Some instances of causal inexplicability do not mean the death of modern science (indeed, otherwise quantum mechanics would pose a serious threat to the wellbeing of science). As William Alston notes in relation to this issue, it happens that medical professionals are surprised by remarkable recoveries by patients; recoveries that they lack good explanations for. Yet, "the conduct of medical science is not at all affected by these inexplicable happenings" (Alston 1994, 49). An instance of divine action that goes contrary to the logic of NDC does not necessarily pose a threat to science.

Clayton's worry becomes even more perplexing when one considers the essential message of his own emergence theory. On Clayton's emergence, which seeks to steer a path between 
both dualism and reductive physicalism, human consciousness depend on natural configurations, yet unpredictable and irreducible to anything physical. Although the emergence of mind is a philosophy extrapolated from chemical and biological models of emergence, it is essential to Clayton's strong emergence theory that science is not able to deliver a full account of human agency. Mental states are both epistemologically and ontologically irreducible, such that the phenomenon of mentality cannot be explicated in terms of natural laws. Thus, if Clayton's emergence theory is true in that it provides a good description of the relationship between mind and matter, then a human being causally contributing to the world would have to be seen as a form of interventionism - that is, a causal event for which we can provide no full scientific account. Nevertheless, Clayton does not seem to think that human agency poses a problem for the practice of science. This, of course, begs the question: why is it that irreducible divine causality causes a problem for science if irreducible human causality does not? In the end, this pragmatic defense of NDC seems unsuccessful, and we need to look for (should we desire one) another line of demarcation between theistic evolution and intelligent design.

\section{Conclusion}

In the fight to hold together belief in God and Darwinian Evolution, intelligent design and theistic evolution have been presented as two competing perspectives, and the war between them has been bitter. Several notable theistic evolutionists present their view that God only acts through natural causes as both theologically and scientifically superior. However, as I have argued in this paper, the often-assumed line of demarcation between theistic evolution and intelligent design is blurred. The central line of demarcation is often presented as differing models of divine action, with intelligent design supporting supernatural intervention and theistic evolution supporting, what I have called, Natural Divine Causation; God only 
acts through and within natural phenomena. On this compatibilist model, God's action never competes with the workings of nature. In the dialogue between science and religion, NDC has been construed as a way to distinguish the framework of theistic evolution from the core claims of intelligent design.

I critically evaluated the NDC account through the causal exclusion principle, and argued that NDC encounters the philosophical problem of overdetermination; we cannot posit two sufficient explanations for one single event. It was seen that NDC runs the risk of making God-talk superfluous. I then investigated if NDC could be understood in terms of partial causation (a view of causation able to avoid overdetermination), but it was seen that partial causation is incompatible with the kind of ontological unity that NDC-supporters seek to uphold between natural processes and divine action.

I then investigated four possible ways of defending NDC: by articulating genuine cases of overdetermination, by construing NDC through Thomism, by conceptualizing NDC through Van Till's view of creation as "optimally equipped", and by arguing for the pragmatic necessity of NDC. While some of these lines of defence could avoid the problem of causal overdetermination, they produced other costly philosophical and theological consequences.

The conclusion has been that Natural Divine Causation cannot function as the desired line of demarcation between theistic evolution and intelligent design. $\frac{6}{6}$

\section{Bibliography}

Alexander, Denis R. 2008. Creation or Evolution: Do we have to choose? Oxford, UK and Grand Rapids, Michigan, USA: Monarch Books.

Alston, William P. 1994. "Divine Action: Divine or Substance?" In The God Who Acts: Philosophical and Theological Explorations, ed. Thomas F. Tracy, 41-62. Pennsylvania: Pennsylvania University Press.

6 I would like to thank two anonymous reviewers for their many helpful comments and suggestions. 
Ayala, Francisco J. "From Paley to Darwin: Design to Natural Selection." In Back to Darwin: A Richer Account of Evolution, ed. John B. Cobb Jr., 50-75. Grand Rapids: William B.

Eerdmans Publishing Company.

Austriacto, Nicanor PG. 2003. "In Defense of Double Agency in Evolution: A response to Five Modern Critics.” Angelicum 80: 947-966.

Behe, Michael J. 2006. Darwin's Black Box: The Biochemical Challenge to Evolution. New York, London, Toronto, Sydney: Free Press.

Benovsky, Jiri. 2018. Mind and Matter: Panpsychism, Dual-Aspect Monism, and the Combination Problem. Switzerland: Springer Publishing.

Bunzl, Martin. 1979. "Causal Overdetermination." The Journal of Philosophy 76: 134-150.

Clayton, Philip. 1997. God and Contemporary Science. Edinburgh: Edinburgh University Press.

Clayton, Philip. 2000. "Neuroscience, The Person, and God: An Emergentist Account." Zygon: Journal of Religion and Science 35: 613-652.

Clayton, Philip. 2004. Mind and Emergence: From Quantum to Consciousness. Oxford, UK: Oxford University Press.

Clayton, Philip. 2006. "Conceptual Foundations of Emergence Theory." In The Re

Emergence of Emergence: Hypothesis from Science to Religion, eds. Philip Clayton and Paul Davies, 134. Oxford: Oxford University Press.

Clayton, Philip. 2008. "Towards a Theory of Divine Action That Has Traction." In Scientific Perspectives on Divine Action: Twenty Years of Challenge and Progress, ed. Robert John Russell, Nancey Murphy, and William R Stoeger S.J., 85-110. Vatican City State: Vatican Observatory, and Berkeley, Calif: Center for Theology and the Natural Sciences.

Dawkins, Richard. 1986. The Blind Watchmaker: Why the Evidence of Evolution Reveals a Universe Without Design. New York: W. W. Norton \& Company, Inc.

Dembski, William A. 1999. Intelligent Design: The Bridge Between Science and Theology. Downers Grove, Illinois: InterVarsity Press.

Farrer, Austin. 1967. Faith and Speculation: An Essay in Philosophical Theology. New York: New York University Press.

Forrest, Barbara. 2004. Creationism's Trojan Horse: The Wedge of Intelligent Design. Oxford: Oxford University Press.

Griffin, David R. 2000. Religion and Scientific Naturalism: Overcoming the Conflicts. Albany, NY: State University of New York Press. 
-----. 2008. "Neo-Darwinism and its Religious Implications." In Back to Darwin: A Richer Account of Evolution, ed. John B. Cobb Jr, 268-287. Grand Rapids: William B. Eerdmans Publishing Company.

Haarsma, Deborah B. 2017a. "Evolutionary Creation." In Four Views on Creation, Evolution, and Intelligent Design, eds. Ken Ham, Hugh Ross, Deborah B. Haarsma, and Stephen C. Meyer, 124-153. Grand Rapids: Zondervan.

Haarsma, Deborah B. 2017b. "Response from Evolutionary Creation.” In Four Views on Creation, Evolution, and Intelligent Design, eds. Ken Ham, Hugh Ross, Deborah B. Haarsma, and Stephen C. Meyer, 221-226. Grand Rapids: Zondervan.

Haught, John F. 2007. "Darwin, Design, and Divine Providence." In Debating Design: From Darwin to DNA, eds. William A. Dembski and Michael Ruse, 229 245. Cambridge: Cambridge University Press.

Johnston, Mark. 2009. Saving God: Religion after Idolatry. Princeton, NJ: Princeton University Press.

Johnson, Phillip E., and Denis O. Lamoureux. 1999. Darwinism Defeated? The JohnsonLamoureux Debate on Biological Origins. Vancouver, Canada: Regent College Publishing.

Kim, Jaegwon. 1988. "Explanatory Realism, Causal Realism, and Explanatory Exclusion. Midwest Studies in Philosophy 12: 225-239.

1993. Supervenience and Mind: Selected Philosophical Essays. New York, NY. Cambridge University Press.

-----. 1998. Mind in a Physical World. Cambridge, MA: MIT Press.

------. 2005. Physicalism, or Something Near Enough. Princeton: Princeton University Press.

-----. 2006. “Emergence: Core Ideas and Issues.” Synthese 151: 547:559.

Knight, Christopher C. 2009. "Theistic Naturalism and 'Special' Divine Providence." Zygon: Journal of Religion and Science 44: 533-542.

Kojonen, Erkki Vesa Rope. 2013. "Tensions in Intelligent Design's Critique of Theistic Evolutionism." Zygon: Journal of Religion and Science 48: 251-273.

\section{------. 2016. The Intelligent Design Debate and the Temptation of Scientism. New York: Routledge. \\ Lamoureux, Denis O. 2008. Evolutionary Creation: A Christian Approach to Evolution. Eugene, OR: Wipf \& Stock.}

Menuge, Angus. 2007. "Who's Afraid of ID? A Survey of the Intelligent Design Movement." In Debating Design: From Darwin to DNA, eds. William A. Dembski and Michael Ruse, 3251. Cambridge: Cambridge University Press. 
Meyer, Stephen C. 2009. Signature in the Cell: DNA and the Evidence for Intelligent Design. New York: HarperCollins.

Meyer, Stephen C. 2017. "Intelligent Design.” In Four Views on Creation, Evolution, and Intelligent Design, eds. Ken Ham, Hugh Ross, Deborah B. Haarsma, and Stephen C. Meyer, 177-208. Grand Rapids: Zondervan.

Monton, Bradley. 2009. Seeking God in Science: An Atheist Defends Intelligent Design. Ontaria, Canada: Broadview Press.

Moore, Dwayne. "Causal Exclusion and Dependent Overdetermination." Erkenntnis 76: 319$\underline{335 .}$

MeGinn, Colin. 1989. "Can We Solve the Body Mind Problem?” Mind 98: 349366.

Parry, Robin. 2017. "God is more than an Intelligent Designer." BioLoges, 15 Nov. 2017, https://biologos.org/blogs/brad-kramer-the-evolving-evangelical/god-is-more-than-anintelligent designer.

Peacocke, Arthur. 1993. Theology for a Scientific Age: Being and Becoming - Natural, Divine, and Human. Minneapolis: Fortress Press.

Peacocke, Arthur. 2001a. "Welcoming the 'Disguised' Friend - Darwinism and Divinity." In Intelligent Design Creationism and Its Critics: Philosophical, Theological, and Scientific Perspectives, ed. Robert T. Pennock, 471- 486. Cambridge, MA, and London, England: MIT Press.

Peacocke, Arthur. 2001b. Paths from Science Towards God: The End of All Exploring. Oxford: Oneworld Publications.

Peacocke, Arthur. "Naturalism, Theism, and Religion." In All that Is: A Naturalistic Faith for the Twenty-First Century, ed. Philip Clayton, 5-11. Minneapolis: Fortress Press.

Peacocke, Arthur. 2006. "Emergence, Mind, and Divine Action: The Hierarchy of the Sciences in Relation to the Human Mind-Brain-Body." In The Re-Emergence of Emergence: The Emergentist Hypothesis form Science to Religion, eds. Philip Clayton and Paul Davies, 257-278. Oxford and New York: Oxford University Press.

Plantinga, Alvin. 2001. "When Faith and Reason Clash: Evolution and the Bible." In Intelligent Design Creationism and Its Critics: Philosophical, Theological, and Scientific Perspectives, ed. Robert T. Pennock, 113-145. Cambridge, MA, and London, England: MIT Press.

Ratzsch, Del. 2001. Nature, Design, and Science: The Status of Design in Natural Science. New York: State University of New York Press.

Russell, Robert J. 2008. Cosmology from Alpha to Omega. Minneapolis, MN: Fortress Press.

Silva, Ignacio. 2014. "Revisiting Aquinas on Providence and Rising Challenge of Divine Action in Nature." The Journal of Religion 94: 277-291. 
-----. 2016. "Divine Action and Thomism: Why Thomas Aquinas's Thought Is Attractive Today." Acta Philosophica 25: 65-84.

Stenmark, Mikael. 2012. “Theories of Human Nature: Key Issues.” Philosophy Compass 7/8: 543-558.

Stek, John H. 1990. "What Says Scripture?” In Portraits of Creation: Biblical and Scientific Perspectives on the World's Formation, ed. Howard J. Van Till, Robert E. Snow, John H. Stek, and Davis A. Young, 203-265.

Van Inwagen, Peter. 2003. "The Compatibility of Darwinism and design.” In God and Design: A Teleological Argument and Modern Science, ed. Neil A. Manson, 348-363. London and New York: Routledge.

Van Till, Howard J. 2001. “The Creation: Intelligently Designed or Optimally Equipped.” In Intelligent Design Creationism and Its Critics: Philosophical, Theological, and Scientific Perspectives, ed. Robert T. Pennock, 487-512. Cambridge, MA, and London, England: MIT Press.

Ward, Keith. 2007. Divine Action: Examining God's role in an Open and Emergent Universe. West Conshohocken, PA: Templeton Press.

Van Woudenberg, René and Joelle Rothuizen-van der Steen. 2015. "Both Random and Guided." Ratio 28: 332-348.

Formatted: Swedish (Sweden)

Formatted: English (United Kingdom)

Formatted: English (United Kingdom)

Formatted: English (United Kingdom) 